\title{
Review \\ Bench-to-bedside review: Metabolism and nutrition
}

Michaël P Casaer, Dieter Mesotten and Miet RC Schetz

Department of Intensive Care Medicine, University Hospital Leuven, Catholic University of Leuven, Herestraat 49, B-3000 Leuven, Belgium

Corresponding author: Michaël P Casaer, michael.casaer@uz.kuleuven.ac.be

Published: 19 August 2008

This article is online at http://ccforum.com/content/12/4/222

(c) 2008 BioMed Central Ltd

Critical Care 2008, 12:222 (doi:10.1186/cc6945)

\begin{abstract}
Acute kidney injury (AKI) develops mostly in the context of critical illness and multiple organ failure, characterized by alterations in substrate use, insulin resistance, and hypercatabolism. Optimal nutritional support of intensive care unit patients remains a matter of debate, mainly because of a lack of adequately designed clinical trials. Most guidelines are based on expert opinion rather than on solid evidence and are not fundamentally different for critically ill patients with or without AKI. In patients with a functional gastrointestinal tract, enteral nutrition is preferred over parenteral nutrition. The optimal timing of parenteral nutrition in those patients who cannot be fed enterally remains controversial. All nutritional regimens should include tight glycemic control. The recommended energy intake is 20 to $30 \mathrm{kcal} / \mathrm{kg}$ per day with a protein intake of 1.2 to $1.5 \mathrm{~g} / \mathrm{kg}$ per day. Higher protein intakes have been suggested in patients with AKI on continuous renal replacement therapy (CRRT). However, the inadequate design of the trials does not allow firm conclusions. Nutritional support during CRRT should take into account the extracorporeal losses of glucose, amino acids, and micronutrients. Immunonutrients are the subject of intensive investigation but have not been evaluated specifically in patients with AKI. We suggest a protocolized nutritional strategy delivering enteral nutrition whenever possible and providing at least the daily requirements of trace elements and vitamins.
\end{abstract}

\section{Introduction}

Patients with acute kidney injury (AKI) have a high prevalence of malnutrition, a condition that is associated with morbidity and mortality [1]. AKI develops mostly in the context of critical illness and multiple organ failure, which are associated with major changes in substrate metabolism and body composition, overwhelming the alterations induced by AKI itself. Key effectors of these changes are inflammatory mediators and neuroendocrine alterations. The development of AKI further adds fluid overload, azotemia, acidosis, and electrolyte disturbances. In addition, AKI is associated with increased inflammation and oxidative stress [2]. The most severe cases of $A K I$ require renal replacement therapy (RRT), with continuous treatments (continuous renal replacement therapy, CRRT) being the modality of choice in most intensive care units (ICUs) [3]. These extracorporeal treatments facilitate nutritional support but may, on the other hand, induce derangements of nutrient balances. The rationale for nutrition during critical illness is mainly to attenuate the catabolism and the loss of lean body mass in the hypermetabolic critically ill patient. However, the concept of improving clinical outcome by improving energy and nitrogen balance is still being challenged [4]. The purposes of this paper were to review the metabolic alterations underlying critical illness and $\mathrm{AKI}$, to discuss nutritional and metabolic support in these patients, and to address the nutritional implications of CRRT. The reader is also referred to several other reviews on this subject [5-10].

\section{Metabolic alterations in critical illness and acute kidney injury}

Critical illness is generally recognized as a hypermetabolic state, with energy expenditure (EE) being proportional to the amount of stress $[11,12]$. Although active solute transport in a functioning kidney is an energy-consuming process, the presence of AKI by itself (in the absence of critical illness) does not seem to affect resting EE (REE) [13]. EE in AKI patients is therefore determined mainly by the underlying condition. Studies in chronic kidney disease yield conflicting results varying between increased [14,15], normal [16], or even decreased REE [17].

A characteristic of critical illness is the so-called 'diabetes of stress' with hyperglycemia and insulin resistance. Hepatic gluconeogenesis (from amino acids and lactate) increases mainly due to the action of catabolic hormones such as glucagon, epinephrine, and cortisol. In addition, the normal suppressive action of exogenous glucose and insulin on hepatic gluconeogenesis is decreased. Peripheral glucose utilization in insulin-dependent tissues (muscle and fat) is also decreased $[18,19]$. Since most patients with AKI also have an underlying critical illness, it is not surprising that the same

$\mathrm{AKI}=$ acute kidney injury; $\mathrm{CO}_{2}=$ carbon dioxide; $\mathrm{CRRT}=$ continuous renal replacement therapy; $\mathrm{EE}=$ energy expenditure; $\mathrm{EN}=$ enteral nutrition; $\mathrm{ESPEN}=$ European Society for Enteral and Parenteral Nutrition; ICU = intensive care unit; MOD = multiple organ dysfunction; PN = parenteral nutrition; RCT = randomized controlled trial; REE = resting energy expenditure; RRT = renal replacement therapy. 
picture is seen in AKI patients [20]. In normal conditions, the kidney plays an important role in glucose homeostasis, contributing to $15 \%$ to $25 \%$ of glucose release in the postabsorptive state (mainly gluconeogenesis from lactate and glutamine) and $10 \%$ to $20 \%$ of glucose uptake $[21,22]$. Whether the loss of kidney function by itself contributes to the altered carbohydrate metabolism in AKI is not clear. Endotoxin injection in mice provoked a downregulation of the GLUT-2 and SGLT-2 transporters responsible for glucose reabsorption in the convoluted segment of the proximal renal tubule. These pathophysiological changes-if applicable to humans-may further complicate glucose homeostasis during AKI [23].

The most striking metabolic feature of critical illness is protein catabolism and net negative nitrogen balance. The increased protein synthesis is unable to compensate for the higher proteolysis. Major mediators are the previously mentioned catabolic hormones and cytokines and the reduced anabolic influence of growth hormone, insulin, and testosterone $[18,19]$. In the acute phase, this catabolic response may be beneficial, providing amino acids for hepatic gluconeogenesis (supplying substrate for vital tissues such as the brain and immune cells) and for synthesis of proteins involved in immune function and in the acute-phase response. However, the sustained hypercatabolism in the chronic phase of critical illness results in a substantial loss of lean body mass and in muscle weakness and decreased immune function. In patients with advanced chronic renal failure, acidosis promotes proteolysis by activating the ubiquitin-proteasome pathway and branched-chain keto acid dehydrogenase [24]. Whether this contributes significantly to the catabolism of AKI patients has not been determined. In patients with AKI, (normalized) protein catabolic rates between 1.3 and 1.8 $\mathrm{g} / \mathrm{kg}$ per day have been noted [25-27]. Protein catabolism will also accelerate the increases of serum potassium and phosphorus that are seen in renal dysfunction.

Changes in lipid metabolism in critically ill patients are ill characterized. The increased catecholamine, growth hormone, and cortisol levels in stress states stimulate lipolysis in peripheral adipose stores. The released free fatty acids are incompletely oxidized (hyperglycemia/hyperinsulinemia exerting an inhibitory effect on lipid oxidation), the remaining being reesterified and resulting in increased hepatic triglyceride production and secretion in very-low-density lipoproteins [18]. Whether triglyceride levels are increased depends on the efficacy of lipoprotein lipase-mediated lipolysis and tissue uptake of remnant particles which is impaired in severe stress situations [28]. Increased triglyceride levels, an impaired lipoprotein-lipase activity, and reduced clearance of exogenous lipids have also been described in AKI patient populations [29].

\section{Nutritional and metabolic support in critical illness and acute kidney injury}

Although there are no large randomized controlled trials (RCTs) investigating the effect of nutritional support versus starvation in this setting, most ICU patients receive nutritional support in an attempt to counteract the catabolic state. The timing, route, and ideal composition of ICU nutritional support remain a matter of discussion and even official guidelines and consensus statements are not always consistent [30-35]. This is also the case for meta-analyses and systematic reviews [3639] and is due mainly to the absence of adequately powered randomized trials, the inadequate design of available clinical studies, and the heterogeneity of the patients.

The traditional ICU doctrine is that enteral nutrition (EN) is always better than parenteral nutrition (PN) because 'it keeps the intestinal mucosa active and reduces bacterial translocation' [33-35]. Compared with standard care, EN indeed may reduce mortality [38]. However, meta-analyses comparing EN with PN did not establish a difference in mortality and the lower incidence of infectious complications with EN may be explained largely by the higher incidence of hyperglycemia in patients receiving PN $[36,39]$. On the other hand, enteral feeding is likely to be cheaper [40-43] and critically ill patients therefore should be fed according to the functional status of their gastrointestinal tractus.

Feeding of critically ill patients should be started early [33-35]. Early nutrition is defined as the initiation of nutritional therapy within 48 hours of either hospital admission or surgery $[34,44]$. A meta-analysis of early versus late EN showed reduced infectious complications and length of hospital stay with early EN, but no effect on noninfectious complications or mortality [45]. However, enterally fed critically ill patients often do not meet their nutritional targets, especially in the first days of ICU stay [46,47]. Adequate early nutrition is easier with the parenteral route and most of the mortality benefits of $\mathrm{PN}$ were indeed established in comparison with late EN [37,48], suggesting that PN should be given to patients in whom EN cannot be initiated within 24 hours of ICU admission [49]. The optimal timing for PN to be initiated is still debated $[44,50]$. The clinical impact of early versus late $\mathrm{PN}$ in addition to EN in critically ill patients is actually being studied in our center (EPaNIC [Impact of Early Parenteral Nutrition Completing Enteral Nutrition in Adult Critically III Patients] trial [51]).

The optimal amount of calories to provide to critically ill patients is unclear. Overfeeding should be avoided in order to prevent hyperglycemia, excess lipid deposition, azotemia, excess carbon dioxide $\left(\mathrm{CO}_{2}\right)$ production with difficult weaning from the respirator, and infectious complications [52-54]. Although not based on solid evidence, recent recommendations suggest a nonprotein energy supply of 25 to $30 \mathrm{kcal} / \mathrm{kg}$ per day in men and 20 to $25 \mathrm{kcal} / \mathrm{kg}$ per day in women, with the lowest values being used in the early phase and in patients older than 60 years [31,34].The proposed proportions of nonprotein energy supply are $60 \%$ to $70 \%$ of carbohydrate and $30 \%$ to $40 \%$ of fat. Whether caloric intake, adjusted to measured EE, improves outcome remains to be 
proven. The gold standard for measuring EE in critically ill patients is indirect calorimetry. It appears to perform better than predictive equations with added stress factors $[55,56]$. However, the use of indirect calorimetry in critically ill patients also has theoretical and practical limitations. Results may become unreliable due to variations in ventilator settings, air leaks, high $\mathrm{FiO}_{2}$ (fraction of inspired oxygen), acid-base disturbances, intermittent feeding, diet-induced thermogenesis, absence of a quiet thermoneutral environment, pain, agitation, and so on [57-59]. Its use during CRRT is discussed below.

The results from two recent trials incited renewed interest in hypocaloric feeding, combining normal protein with reduced caloric supply. An RCT showed fewer infectious complications and reduced ICU stay with less aggressive (and markedly hypocaloric) early EN, suggesting that the clinician should weigh the complications of full-target early EN against its benefits [60]. An observational trial, evaluating the consistency of current feeding regimens with existing guidelines, found that caloric intake of between 33\% and $66 \%$ of the target was associated with better survival [61]. The rationale for hypocaloric feeding is to provide nutrition without exacerbating the stress response. It is, however, evident that this needs to be validated in an adequately powered RCT [62]. The rationale against hypocaloric feeding is that patients receiving less than their REE will inevitably develop negative energy balances [63]. Two observational trials observed an association between a worse clinical outcome and a negative cumulative energy balance [64] or a caloric intake of below 25\% of American College of Chest Physicians recommended targets [65].

Nutritional support often results in an aggravation of hyperglycemia, an effect that is more pronounced with $P N$ than with EN [66]. Multiple observational trials in different types of critically ill patients have shown an association between hyperglycemia and morbidity and/or mortality. A cause-andeffect relationship was confirmed in two large prospective randomized clinical trials that have shown an improved morbidity and mortality with tight glycemic control with insulin infusion in fed critically ill patients $[67,68]$. This treatment strategy also reduced the incidence of AKI [69]. Prevention of glucose toxicity in tissues not depending on insulin for glucose uptake is the proposed underlying mechanism $[70,71]$. Other metabolic effects were an improved lipid profile [72] and reduced insulin resistance [73]. The beneficial effect of intensive insulin therapy was not confirmed by a recent prospective randomized trial in patients with severe sepsis. However, this study was stopped prematurely because of a high rate of hypoglycemia and therefore was tenfold underpowered [74]. Any nutritional protocol in ICU patients with or without AKI should therefore include tight glycemic control.

Proteins are administered in an attempt to improve protein synthesis and nitrogen balance. Although negative nitrogen balances are associated with worse outcome, there are no randomized studies comparing different protein or nitrogen intakes with regard to clinical outcomes in ICU patients. Although the ideal amount is still debated [4], a protein intake of between 1.2 and $1.5 \mathrm{~g} / \mathrm{kg}$ per day $(0.16$ to $0.24 \mathrm{~g}$ nitrogen/kg per day) is usually recommended $[19,30,75]$. Because many nonessential amino acids are not readily synthesized or increasingly used in critically ill patients, the combination of essential and nonessential amino acids is supposed to be superior.

\section{Role of specific components Glutamine}

Glutamine is the most abundant amino acid in the body and is an important fuel for cells of the immune system. In stress situations, its serum and intracellular concentrations decrease and it becomes a 'conditionally' essential amino acid. Although not all clinical trials show a beneficial effect [76], the available guidelines recommend enteral glutamine supplementation in trauma and burn patients and high-dose parenteral supplementation in general ICU patients receiving total PN [33-35].

\section{Antioxidant micronutrients}

Micronutrients (vitamins and trace elements) play a key role in metabolism, immune function, and antioxidant processes. They are deficient in critically ill patients and should be supplemented, although the precise requirements have not been determined. In particular, the antioxidants selenium, zinc, vitamin $\mathrm{E}$, and vitamin $\mathrm{C}$ have shown promising effects on infectious complications and/or mortality in ICU patients [77-80]. With the exception of vitamin C, levels of antioxidant vitamins and trace elements are not different in the presence of AKI [81]. Recommended vitamin C intake in AKI varies between 30 to $50 \mathrm{mg} /$ day [82] and $100 \mathrm{mg}$ [6]. Theoretically, the presence of AKI might even increase the potential role of antioxidants. When compared with a group of matched critically ill patients, AKI patients have increased oxidative stress, reflected by lower plasma protein thiol content and higher plasma carbonyl content [2]. A smaller study also confirmed that multiple organ dysfunction (MOD) with AKI resulted in more oxidative stress and a stronger depletion of the antioxidative system than MOD alone [81].

\section{Immunonutrients}

Nutrients with an immune-modulating effect, including glutamine, arginine, nucleotides, and omega-3 fatty acids, have been the subject of intensive investigation [83]. Data on immunonutrition in $\mathrm{AKI}$ are scarce and the number of patients suffering from $\mathrm{AKI}$ on inclusion is not reported in most studies. Arginine is a precursor of nitric oxide synthesis and may be detrimental in critically ill patients with an ongoing inflammatory response $[84,85]$. Meta-analysis aggregating the results of three RCTs of enteral supplementation of omega-3 fatty acids (fish oil) in patients with acute respiratory distress syndrome demonstrated that enteral formula 
enriched with fish oils significantly reduces mortality and ventilator days and tended to reduce ICU length of stay [85]. A role for exogenous omega-3 fatty acids in human renal protection is, at this moment, purely speculative [86].

Others have evaluated cocktails of several immunonutients. A large RCT ( $n=597$ patients) comparing enteral immunonutrition (containing glutamine, arginine, nucleotides, and omega-3 fatty acids) with standard EN in critically ill patients showed no difference in clinical outcome [87], which was confirmed by a recent meta-analysis [85]. Another clinical trial evaluated an enteral pharmaconutrient cocktail in 55 septic patients, the majority of whom were on CRRT. The primary outcome parameter, the change in sequential organ failure score, improved with the pharmaconutrient, whereas mortality and ICU and hospital lengths of stay were not affected [88].

\section{Recommendations for nutrition during acute kidney injury in the intensive care unit}

In ICU patients with AKI, the recommendations for nutritional support are largely the same as for other ICU patients $[6,9,82]$. We provide an overview of the nutritional strategy during $\mathrm{AKI}$ with references to the available evidence (Table 1). Introduction of a nutritional management protocol improved nutrition delivery and clinical outcome in two nonrandomised trials $[89,90]$. Standardization of $P N$ is suggested by recent guidelines of the American Society for Parenteral and Enteral Nutrition [91]. The European Society for Enteral and Parenteral Nutrition (ESPEN) recommends 0.6 to $0.8 \mathrm{~g}$ protein $/ \mathrm{kg}$ per day in case of conservative therapy, 1 to $1.5 \mathrm{~g} / \mathrm{kg}$ per day with extracorporeal treatment, and a maximum of $1.7 \mathrm{~g} / \mathrm{kg}$ per day in 'hypercatabolism' [82]. Possible restrictions to adequate nutrition in AKI are fluid overload (requiring more concentrated solutions), electrolyte disturbances (requiring electrolyte-free solutions), and the increased urea generation associated with a large amount of protein intake. Older and largely underpowered studies showed controversial effects of the addition of amino acids to glucose on mortality and renal recovery [92-94]. Most recent studies on nutritional support in AKI patients have been performed during CRRT and will be discussed in the next section. EN in AKI is, in general, safe, although increased gastric residual volumes have been described in comparison with non-AKI ICU patients [95]. The ability to provide EN is associated with improved outcome [96]. No clinical trials have specifically addressed the effect of immunonutrition in AKI patients.

\section{Nutritional support during continuous renal replacement therapy}

CRRT allows unrestricted nutritional support, reaching nutritional targets without the risk of fluid overload and excessive urea levels. The effect of CRRT on EE and protein catabolic rate is probably small and not clinically relevant. A small observational study found no change in REE before and after the start of CRRT [97]. CRRT frequently induces hypo- thermia, the degree of which correlates with the ultrafiltration rate [98]. This hypothermia represents thermal energy loss [99] but also reduces REE, especially if not associated with shivering $[98,100]$. Studies by Gutierrez and colleagues in the early 1990s suggested that blood-membrane contact during RRT may induce a protein catabolic effect, an effect that was seen only with cuprophane membrane and not with synthetic membranes [101] and was not reduced by the addition of glucose to the dialysate [102]. Compared with intermittent hemodialysis, the use of CRRT simplifies the calculation of protein catabolic rate [27].

Several studies have evaluated nutritional support during CRRT in AKI patients. Unfortunately, neither of these used clinically relevant outcomes. Fiaccadori and colleagues [103] used a crossover design to compare the combination of $1.5 \mathrm{~g}$ protein $/ \mathrm{kg}$ per day with 30 or $40 \mathrm{kcal} / \mathrm{kg}$ per day. The higher energy provision did not improve nitrogen balance, protein catabolism, and urea generation rate but resulted in increased metabolic complications, including hypertriglyceridemia and hyperglycemia [103]. In an observational study using regression techniques, Macias and colleagues [26] showed that high-protein intakes, required to achieve nitrogen balance, may increase protein catabolism, especially if combined with high caloric intake. The authors therefore suggest an energy intake of 25 to $35 \mathrm{kcal} / \mathrm{kg}$ per day with a protein intake of 1.5 to $1.8 \mathrm{~g} / \mathrm{kg}$ per day. Other authors have suggested higher protein intake. An early observational study showed that higher protein input (up to $2.5 \mathrm{~g} / \mathrm{kg}$ per day) results in a less negative nitrogen balance, but at the expense of higher azotemia and CRRT requirement [104]. The same authors showed positive nitrogen balances in 35\% of the patients with protein intakes of $2.5 \mathrm{~g} / \mathrm{kg}$ per day [105]. Scheinkestel and colleagues [106] randomly assigned CRRT patients to $2 \mathrm{~g}$ protein $/ \mathrm{kg}$ per day or escalating doses (1.5, 2.0 , and $2.5 \mathrm{~g} / \mathrm{kg}$ per day), energy intake being isocaloric in both groups. Protein intake correlated with nitrogen balance, and nitrogen balance correlated with survival, but, surprisingly, protein intake did not correlate with survival. In addition, in contrast to what the title suggests, this is not a randomized trial comparing high- versus low-protein intake [106]. More research, using adequate design and endpoints, is therefore needed before larger protein loads can be recommended in AKI patients on CRRT. The problem is that we do not know the metabolic fate of the administered amino acids that may be used for synthesis of 'beneficial' proteins but that may also be burnt or even join the inflammatory mediator pool.

Nutritional support during CRRT should take into account the extracorporeal losses of nutrients. Most clinical studies on glucose dynamics during CRRT were performed in the early 1990s, often with arteriovenous techniques and low effluent rates in patients receiving PN [107-110]. The net loss or gain of glucose induced by CRRT depends on the balance between glucose losses in the ultrafiltrate and/or effluent 
Table 1

Nutritional strategy in patients with acute kidney injury in the Department of Intensive Care Medicine, University Hospital Leuven

\begin{tabular}{|c|c|c|}
\hline & & Reference(s) \\
\hline \multirow[t]{2}{*}{$\begin{array}{l}\text { Protocolized prescription for } \\
\text { artificial nutrition }\end{array}$} & $\begin{array}{l}\text { Caloric target: } 24,30 \text {, and } 36 \mathrm{kcal} / \mathrm{kg} \text { protein included, based on age, gender, } \\
\text { and corrected ideal body weight. }\end{array}$ & {$[31,34,89,90]$} \\
\hline & $\begin{array}{l}\text { Target and energy provisions of previous day shown in Patient Data Management } \\
\text { System. Energy from sources other than PN is included. }\end{array}$ & \\
\hline ‘Early’ EN & $\begin{array}{l}\text { EN is initiated within } 36 \text { hours from admission unless (a) formal contraindication } \\
\text { (for example, high gastrointestinal fistula, intestinal ischemia, and high-dose } \\
\text { vasopressor) or (b) the patient is starting to eat. }\end{array}$ & {$[32,34,45,96]$} \\
\hline $\begin{array}{l}\text { Progressive increase of EN dose } \\
\text { during hospitalization }\end{array}$ & $\begin{array}{l}\text { Day 2: } 200 \text { to } 500 \mathrm{kcal} \\
\text { Day 3: } 700 \text { to } 900 \mathrm{kcal} \\
\text { Day 4: } 1,100 \text { to } 1,300 \mathrm{kcal} \\
\text { Day 5: } 1,500 \text { to } 1,700 \mathrm{kcal}\end{array}$ & {$[60]$} \\
\hline \multirow[t]{2}{*}{$\begin{array}{l}\text { PN: according to randomization in } \\
\text { ongoing EPaNIC trial }\end{array}$} & $\begin{array}{l}\text { Early PN: within } 48 \text { hours of initiation of standard PN to complement EN up to } \\
100 \% \text { of caloric target, unless patient is starting to eat. }\end{array}$ & {$[44,50]$} \\
\hline & Late PN: no PN during the first week after admission on the ICU. & [51] \\
\hline Standardized formulations & Commercially available ready-to-use EN and PN preparations. & [91] \\
\hline Composition of EN and PN & $\begin{array}{l}60 \% \text { to } 70 \% \text { dextrose, } 30 \% \text { to } 40 \% \text { lipids. } \\
\text { Lipids less than } 1 \mathrm{~g} \text { lipids/kg body weight per day. } \\
\text { Proteins: } 0.8 \text { to } 1.2 \mathrm{~g} / \mathrm{kg} \text { body weight per day. } \\
\text { No adaptation for acute renal failure and/or CRRT. } \\
\text { Use of glucose-containing replacement fluid (physiological concentration) in CRRT. }\end{array}$ & {$[4,10,19]$} \\
\hline \multirow[t]{2}{*}{ Parenteral lipid restriction } & $\begin{array}{l}\text { If plasma triglycerides are greater than } 300 \mathrm{mg} / \mathrm{dL} \text {. Lipid-free PN is administered } \\
\text { and lipids are added once weekly. }\end{array}$ & {$[10,29]$} \\
\hline & Glucose administration in binary PN should not exceed $5 \mathrm{~g} / \mathrm{kg}$ per day. & \\
\hline \multirow[t]{3}{*}{ Volume and electrolyte restriction } & $\begin{array}{l}\text { In case of fluid overload, renal replacement therapy will be started rather than } \\
\text { PN or EN volume reduced. }\end{array}$ & [6] \\
\hline & $\begin{array}{l}\text { Concentrated EN is used only during prolonged critical illness with intermittent } \\
\text { hemodialysis. }\end{array}$ & \\
\hline & Electrolyte-free standard formulations are used on indication. & \\
\hline Strict glycemic control & $\begin{array}{l}\text { All patients in the ICU receive insulin targeted at blood glucose levels of } \\
80 \text { to } 110 \mathrm{mg} / \mathrm{dL} \text {. }\end{array}$ & {$[67,68]$} \\
\hline \multirow[t]{2}{*}{ Vitamins and trace elements } & $\begin{array}{l}\text { All patients requiring nutritional support receive recommended daily allowances of } \\
\text { parenteral trace elements and vitamins until they receive more than } 1,600 \text { kcal } \\
\text { standard enteral formulation. }\end{array}$ & {$[85,123,125]$} \\
\hline & $\begin{array}{l}\text { During severe hepatic failure, doses of manganese and copper are reduced to } \\
\text { once weekly. }\end{array}$ & [127] \\
\hline Immunonutrition & No routine use of enteral or parenteral immunonutrients. & [85] \\
\hline $\begin{array}{l}\text { Frequent monitoring of electrolytes } \\
\text { and lactate }\end{array}$ & $\begin{array}{l}\text { Potassium, bicarbonate, and lactate every } 4 \text { hours. } \\
\text { Sodium, chlorine, magnesium, and phosphorous every } 24 \text { hours. }\end{array}$ & {$[82,115]$} \\
\hline
\end{tabular}

CRRT, continuous renal replacement therapy; EN, enteral nutrition; ICU, intensive care unit; PN, parenteral nutrition.

dialysate and the glucose administered via the replacement fluid or dialysate. Extracorporeal losses can be compensated by the use of physiological levels of glucose in the replacement fluid or dialysate, the ideal level probably being the target level suggested by the randomized trials on tight glycemic control $[67,68]$. Supraphysiological levels may result in hyperglycemia and should be avoided. 'Modern' CRRT, using higher effluent rates, will accentuate extracorporeal glucose losses that, on the other hand, can be reduced by tight glycemic control. Assuming a glucose-free replacement fluid, a blood glucose level of $100 \mathrm{mg} / \mathrm{dL}$ with a filtration or dialysate flow rate of $2.5 \mathrm{~L} /$ hour will result in a daily extracorporeal glucose loss of $60 \mathrm{~g}$ or $240 \mathrm{kcal} / \mathrm{day}$, whereas a blood level of $150 \mathrm{mg} / \mathrm{dL}$ results in a loss of $90 \mathrm{~g}$ or $360 \mathrm{kcal} / \mathrm{day}$.

The metabolic effects of infusing lactate or citrate should also be taken into account [111]. If entirely oxidized, $1 \mathrm{mmol}$ of 
lactate can provide $0.32 \mathrm{kcal}$ [112]. Assuming a lactate level of $30 \mathrm{mmol} / \mathrm{L}$ in the replacement fluid with a flow rate of $2 \mathrm{~L} /$ hour, this would result in a potential energy provision of $460 \mathrm{kcal}$. Continuous veno-venous hemofiltration, especially if performed with bicarbonate in the replacement fluid, appears to be a risk factor for hypoglycemia [113]. Whether this reflects the higher illness severity of patients receiving bicarbonate instead of lactate or the ability of lactate to serve as a substrate for gluconeogenesis remains to be determined. Compared with bicarbonate, the use of lactate as a buffer in continuous veno-venous hemodiafiltration has indeed been shown to result in higher blood glucose levels and higher glucose turnover [114]. Lactate- or bicarbonatebuffered replacement fluids each induce specific changes in sodium, chloride, magnesium, and phosphate mass balances [115]. The significant extracorporeal phosphate losses may aggravate refeeding hypophosphatemia. Frequent electrolyte monitoring is therefore required [82].

Theoretically, CRRT might also influence metabolic monitoring by inducing extracorporeal loss or gain of $\mathrm{CO}_{2}$. The net effect depends on the $\mathrm{pH}$ of the patient, the use of bicarbonate versus nonbicarbonate buffers, and how fast nonbicarbonate buffers are metabolized to bicarbonate and $\mathrm{CO}_{2}$. Since the changes induced by CRRT are much smaller and slower than with intermittent hemodialysis, the impact is probably minimal. In addition, changes in $\mathrm{VCO}_{2}$ (rate of elimination of $\mathrm{CO}_{2}$ ) result in much smaller errors in the measurement of EE than changes in $\mathrm{VO}_{2}$ (oxygen uptake) of the same magnitude [57].

An additional catabolic factor is the extracorporeal loss of amino acids, which appears to correlate directly with the serum amino acid concentration and the effluent rate $[116,117]$. Sieving coefficients approach 1 except for glutamine that is less efficiently eliminated [117,118]. In trauma patients on continuous hemodiafiltration, daily amino acid losses of between 10 and $15 \mathrm{~g}$ have been reported [116]. Others found extracorporeal losses reaching $4.5 \%$ to $20 \%$ of the daily substitution [105,118-120]. In two studies, glutamine represented $16 \%$ and $33 \%$ of the total losses, respectively [116,119]. Despite the described losses, the serum amino acid profile does not seem to be affected, suggesting that the losses are small compared with the daily turnover [116,117]. Again, these studies were performed more than 10 years ago and used lower effluent rates than are currently recommended.

Since most lipids circulate as lipoproteins or are bound to albumin, extracorporeal losses are not to be expected. Indeed, only trace quantities of cholesterol and triglycerides have been found in the ultradiafiltrate [121].

Water-soluble vitamins and trace elements may be lost during CRRT. Earlier studies are probably less reliable because of the use of less sensitive assays. Markedly different losses of

\section{This article is part of a review series on Renal replacement therapy, edited by John Kellum and Lui Forni.}
Other articles in the series can be found online at http://ccforum.com/articles/ theme-series.asp?series=CC_Renal

selenium have been reported, varying from 'much less than' to 'more than twice' the recommended daily intake [122-125]. Losses of zinc are generally small $[122,125,126]$ and even positive zinc balances (due to the presence of zinc in the replacement solution) have been described [123]. Losses of thiamine may amount to 1.5 times the recommended intake [123], whereas the clinical significance of vitamin C losses remains unclear [122]. The ESPEN guideline states that extracorporeal losses should be supplemented but excessive supplementation may result in toxicity and therefore micronutrient status should be monitored [82].

\section{Conclusion}

AKI and critical illness are characterized by a catabolic state, insulin resistance, and altered carbohydrate and glucose metabolism. These changes are provoked by counterregulatory hormones, acidosis, and cytokines. The contribution of AKI by itself remains difficult to establish. The losses of macronutrients and micronutrients during CRRT further complicate this picture. The optimal nutritional support strategy for patients with $\mathrm{AKI}$ requiring CRRT remains a matter of controversy. It should aim at attenuating tissue wasting and reducing the risk for nutrition-related side effects. The heterogeneity of the patients, the complexity of the disease process, and the inadequate design of the available trials preclude firm conclusions. The available recommendations are based more on expert opinion than on solid evidence. In general, the guidelines of general ICU patients can be followed, with modifications for the extracorporeal nutrient losses. Nutrition probably should be protocolized, aimed at EN whenever possible and providing at least the daily requirements of trace elements and vitamins. Augmented doses of energy, carbohydrates, lipids, and proteins as well as pharmacological doses of immunonutrients should be avoided except in the context of adequately powered RCTs until evidence is available. Any nutritional regimen and any future trial on nutrition in critical illness or AKI should be combined with tight glycemic control.

\section{Competing interests}

MPC has received an unrestricted and nonconditional research grant from Baxter SA France (Maurepas, France). The other authors declare that they have no competing interests. 


\section{References}

1. Fiaccadori E, Lombardi M, Leonardi S, Rotelli CF, Tortorella G, Borghetti A: Prevalence and clinical outcome associated with preexisting malnutrition in acute renal failure: a prospective cohort study. J Am Soc Nephrol 1999, 10:581-593.

2. Himmelfarb J, McMonagle E, Freedman S, Klenzak J, McMenamin E, Le P, Pupim LB, Ikizler TA, The PICARD Group: Oxidative stress is increased in critically ill patients with acute renal failure. J Am Soc Nephrol 2004, 15:2449-2456.

3. Uchino S: The epidemiology of acute renal failure in the world. Curr Opin Crit Care 2006, 12:538-543.

4. Stroud M: Protein and the critically ill; do we know what to give? Proc Nutr Soc 2007, 66:378-383.

5. Lorenzo V: Role of nutritional support in acute renal failure. Curr Op Crit Care 1996, 2:405-412.

6. Bellomo R, Ronco C: How to feed patients with renal dysfunction. Curr Opin Crit Care 2000, 6:239-246.

7. Marin A, Hardy G: Practical implications of nutritional support during continuous renal replacement therapy. Curr Opin Clin Nutr Metab Care 2001, 4:219-225.

8. Chan LN: Nutritional support in acute renal failure. Curr Opin Clin Nutr Metab Care 2004, 7:207-212.

9. Wooley JA, Btaiche IF, Good KL: Metabolic and nutritional aspects of acute renal failure in critically ill patients requiring continuous renal replacement therapy. Nutr Clin Pract 2005 , 20:176-191.

10. Druml W: Nutritional management of acute renal failure. $J$ Ren Nutr 2005, 15:63-70.

11. Hwang TL, Huang SL, Chen MF: The use of indirect calorimetry in critically ill patients-the relationship of measured energy expenditure to Injury Severity Score, Septic Severity Score, and APACHE II Score. J Trauma 1993, 34:247-251.

12. Uehara M, Plank LD, Hill GL: Components of energy expenditure in patients with severe sepsis and major trauma: a basis for clinical care. Crit Care Med 1999, 27:1295-1302.

13. Schneeweiss B, Graninger W, Stockenhuber F, Druml W, Ferenci $\mathrm{P}$, Eichinger S, Grimm G, Laggner AN, Lenz K: Energy metabolism in acute and chronic renal failure. Am J Clin Nutr 1990, 52:596-601.

14. Ikizler TA, Wingard RL, Sun M, Harvell J, Parker RA, Hakim RM: Increased energy expenditure in hemodialysis patients. J Am Soc Nephrol 1996, 7:2646-2653.

15. Neyra R, Chen KY, Sun M, Shyr Y, Hakim RM, Ikizler TA: Increased resting energy expenditure in patients with endstage renal disease. JPEN J Parenter Enteral Nutr 2003, 27:3642.

16. Kamimura MA, Draibe SA, Avesani CM, Canzaini ME, Colugnati FA, Cuppari L: Resting energy expenditure and its determinants in hemodialysis patients. Eur J Clin Nutr 2007, 61:362367.

17. Avesani CM, Draibe SA, Kamimura MA, Dalboni MA, Colugnati FA, Cuppari L: Decreased resting energy expenditure in nondialysed chronic kidney disease patients. Nephrol Dial Transplant 2004, 19:3091-3097.

18. Wolfe RR: Sepsis as a modulator of adaptation to low and high carbohydrate and low and high fat intakes. Eur $\mathrm{J}$ Clin Nutr 1999, 53 Suppl 1:S136-S142.

19. Biolo G, Grimble G, Preiser JC, Leverve X, Jolliet P, Planas M, Roth E, Wernerman J, Pichard C: Position paper of the ESICM Working Group on Nutrition and Metabolism. Metabolic basis of nutrition in intensive care unit patients: ten critical questions. Intensive Care Med 2002, 28:1512-1520.

20. Basi S, Pupim LB, Simmons EM, Sezer MT, Shyr Y, Freedman S, Chertow GM, Mehta RL, Paganini E, Himmelfarb J, Ikizler TA: Insulin resistance in critically ill patients with acute renal failure. Am J Physiol Renal Physiol 2005, 289:F259-F264.

21. Stumvoll M, Meyer C, Mitrakou A, Gerich JE: Important role of the kidney in human carbohydrate metabolism. Med Hypotheses 1999, 52:363-366.

22. Cano N: Bench-to-bedside review: glucose production from the kidney. Crit Care 2002, 6:317-321.

23. Schmidt $C$, Hocherl $K$, Bucher $M$ : Regulation of renal glucose transporters during severe inflammation. Am J Physiol Renal Physiol 2007, 292:F804-F811.

24. Mehrotra R, Kopple J, Wolfson M: Metabolic acidosis in maintenance dialysis patients: clinical considerations. Kidney Int 2003, 88:S13-S25.
25. Chima CS, Meyer L, Hummell AC, Bosworth C, Heyka R, Paganini $E P$, Werynski A: Protein catabolic rate in patients with acute renal failure on continuous arteriovenous hemofiltration and total parenteral nutrition. J Am Soc Nephrol 1993, 3:1516-1521.

26. Macias WL, Alaka KJ, Murphy MH, Miller ME, Clark WR, Mueller $\mathrm{BA}$ : Impact of the nutritional regimen on protein catabolism and nitrogen balance in patients with acute renal failure. JPEN J Parenter Enteral Nutr 1996, 20:56-62.

27. Leblanc M, Garred LJ, Cardinal J, Pichette V, Nolin L, Ouimet D, Geadah D: Catabolism in critical illness: estimation from urea nitrogen appearance and creatinine production during continuous renal replacement therapy. Am J Kidney Dis 1998, 32: 444-453.

28. Carpentier YA, Scruel O: Changes in the concentration and composition of plasma lipoproteins during the acute phase response. Curr Opin Clin Nutr Metab Care 2002, 5:153-158.

29. Druml W, Fischer M, Sertl S, Schneeweiss B, Lenz K, Widhalm K: Fat elimination in acute renal failure: long-chain vs mediumchain triglycerides. Am J Clin Nutr 1992, 55:468-472.

30. Cerra FB, Benitez MR, Blackburn GL, Irwin RS, Jeejeebhoy K, Katz DP, Pingleton SK, Pomposelli J, Rombeau JL, Shronts E, Wolfe RR, Zaloga GP: Applied nutrition in ICU patients. A consensus statement of the American College of Chest Physicians. Chest 1997, 111:769-778.

31. Jolliet P, Pichard C, Biolo G, Chiolero R, Grimble G, Leverve X Nitenberg G, Novak I, Planas M, Preiser JC, Roth E, Schols AM, Wernerman J: Enteral nutrition in intensive care patients: a practical approach. Working Group on Nutrition and Metabolism, ESICM. European Society of Intensive Care Medicine. Intensive Care Med 1998, 24:848-859.

32. ASPEN Board of Directors and the Clinical Guidelines Task Force: Guidelines for the use of parenteral and enteral nutrition in adult and pediatric patients. JPEN J Parenter Enteral Nutr 2002, 26:1SA-138SA.

33. Heyland DK, Dhaliwal R, Drover JW, Gramlich L, Dodek P: Canadian clinical practice guidelines for nutrition support in mechanically ventilated, critically ill adult patients. JPEN J Parenter Enteral Nutr 2003, 27:355-373.

34. Kreymann KG, Berger MM, Deutz NE, Hiesmayr M, Jolliet $P$ Kazandjiev G, Nitenberg G, Van den BG, Wernerman J, Ebner C Hartl W, Heymann C, Spies C: ESPEN Guidelines on Enteral Nutrition: Intensive care. Clin Nutr 2006, 25:210-223.

35. Doig GS, Simpson F: Evidence-Based Guidelines for Nutritional Support of the Critically III: Results of a Bi-national Guideline Development Conference [http://www.evidencebased.net/files/ EBGforNutSupportoflCUpts.pdf]. Sydney, NSW, Australia: EvidenceBased.net; 2005.

36. Gramlich L, Kichian K, Pinilla J, Rodych NJ, Dhaliwal R, Heyland DK: Does enteral nutrition compared to parenteral nutrition result in better outcomes in critically ill adult patients? A systematic review of the literature. Nutrition 2004, 20:843-848.

37. Simpson F, Doig GS: Parenteral vs. enteral nutrition in the critically ill patient: a meta-analysis of trials using the intention to treat principle. Intensive Care Med 2005, 31:12-23.

38. Doig GS, Simpson F: Early enteral nutrition in the critically ill: do we need more evidence or better evidence? Curr Opin Crit Care 2006, 12:126-130.

39. Koretz RL, Avenell A, Lipman TO, Braunschweig CL, Milne AC: Does enteral nutrition affect clinical outcome? A systematic review of the randomized trials. Am J Gastroenterol 2007, 102: 412-429.

40. Borzotta AP, Pennings J, Papasadero B, Paxton J, Mardesic S, Borzotta R, 'Parrott A, Bledsoe F: Enteral versus parenteral nutrition after severe closed head injury. J Trauma 1994, 37: 459-468.

41. Adams S, Dellinger EP, Wertz MJ, Oreskovich MR, Simonowitz D, Johansen K: Enteral versus parenteral nutritional support following laparotomy for trauma: a randomized prospective trial. $J$ Trauma 1986, 26:882-891.

42. Kalfarentzos F, Kehagias J, Mead N, Kokkinis K, Gogos CA: Enteral nutrition is superior to parenteral nutrition in severe acute pancreatitis: results of a randomized prospective trial. Br J Surg 1997, 84:1665-1669.

43. Wicks C, Somasasundaram S, Bjarnason I, Menzies IS, Routley D, Potter D, Tan KC, Williams R: Comparison of enteral feeding and total parenteral nutrition after liver transplantation. Lancet 1994, 344:837-840. 
44. de Aguilar-Nascimento JE, Kudsk KA: Early nutritional therapy: the role of enteral and parenteral routes. Curr Opin Clin Nutr Metab Care 2008, 11:255-260.

45. Marik PE, Zaloga GP: Early enteral nutrition in acutely ill patients: a systematic review. Crit Care Med 2001, 29:22642270.

46. De Jonghe B, Appere-De-Vechi C, Fournier M, Tran B, Merrer J, Melchior JC, Outin $\mathrm{H}$ : A prospective survey of nutritional support practices in intensive care unit patients: what is prescribed? What is delivered? Crit Care Med 2001, 29:8-12.

47. Heyland DK, Schroter-Noppe D, Drover JW, Jain M, Keefe L, Dhaliwal R, Day A: Nutrition support in the critical care setting: current practice in Canadian ICUs-opportunities for improvement? JPEN J Parenter Enteral Nutr 2003, 27:74-83.

48. Bistrian BR, McCowen KC: Nutritional and metabolic support in the adult intensive care unit: key controversies. Crit Care Med 2006, 34:1525-1531.

49. Heidegger CP, Romand JA, Treggiari MM, Pichard C: Is it now time to promote mixed enteral and parenteral nutrition for the critically ill patient? Intensive Care Med 2007, 33:963-969.

50. Wernerman J: Paradigm of early parenteral nutrition support in combination with insufficient enteral nutrition. Curr Opin Clin Nutr Metab Care 2008, 11:160-163.

51. Impact of Early Parenteral Nutrition Completing Enteral Nutrition in Adult Critically III Patients (EPaNIC) [http://clinicaltrials.gov/ct2/ show/NCT00512122]

52. McClave SA, Lowen CC, Kleber MJ, Nicholson JF, Jimmerson SC, McConnell JW, Jung LY: Are patients fed appropriately according to their caloric requirements? JPEN J Parenter Enteral Nutr 1998, 22:375-381.

53. Klein CJ, Stanek GS, Wiles CE III: Overfeeding macronutrients to critically ill adults: metabolic complications. J Am Diet Assoc 1998, 98:795-806.

54. Dissanaike S, Shelton M, Warner K, O'Keefe GE: The risk for bloodstream infections is associated with increased parenteral caloric intake in patients receiving parenteral nutrition. Crit Care 2007, 11:R114.

55. Reid CL: Poor agreement between continuous measurements of energy expenditure and routinely used prediction equations in intensive care unit patients. Clin Nutr 2007, 26:649657.

56. Flancbaum L, Choban PS, Sambucco S, Verducci J, Burge JC: Comparison of indirect calorimetry, the Fick method, and prediction equations in estimating the energy requirements of critically ill patients. Am J Clin Nutr 1999, 69:461-466.

57. Brandi LS, Bertolini R, Calafa M: Indirect calorimetry in critically ill patients: clinical applications and practical advice. Nutrition 1997, 13:349-358.

58. Branson RD, Johannigman JA: The measurement of energy expenditure. Nutr Clin Pract 2004, 19:622-636.

59. Schutz Y, Thiébaud D, Acheson KJ, Felber JP, Defronzo RA, Jéquier $E$ : Thermogenesis induced by five different intravenous glucose/insulin infusions in healthy young men. Clin Nutr 2008, 2:93-96.

60. Ibrahim EH, Mehringer L, Prentice D, Sherman G, Schaiff R, Fraser $\mathrm{V}$, Kollef $\mathrm{MH}$ : Early versus late enteral feeding of mechanically ventilated patients: results of a clinical trial. JPEN J Parenter Enteral Nutr 2002, 26:174-181.

61. Krishnan JA, Parce PB, Martinez A, Diette GB, Brower RG: Caloric intake in medical ICU patients: consistency of care with guidelines and relationship to clinical outcomes. Chest 2003, 124:297-305

62. Boitano M: Hypocaloric feeding of the critically ill. Nutr Clin Pract 2006, 21:617-622.

63. Berger MM, Chiolero RL: Hypocaloric feeding: pros and cons. Curr Opin Crit Care 2007, 13:180-186.

64. Villet S, Chiolero RL, Bollmann MD, Revelly JP, Cayeux RNM, Delarue J, Berger MM: Negative impact of hypocaloric feeding and energy balance on clinical outcome in ICU patients. Clin Nutr 2005, 24:502-509.

65. Rubinson L, Diette GB, Song X, Brower RG, Krishnan JA: Low caloric intake is associated with nosocomial bloodstream infections in patients in the medical intensive care unit. Crit Care Med 2004, 32:350-357.

66. Peter JV, Moran JL, Phillips-Hughes J: A metaanalysis of treatment outcomes of early enteral versus early parenteral nutrition in hospitalized patients. Crit Care Med 2005, 33:213-220.
67. Van den Berghe G, Wouters P, Weekers F, Verwaest C, Bruyninckx F, Schetz M, Vlasselaers D, Ferdinande P, Lauwers P, Bouillon R: Intensive insulin therapy in the critically ill patients. $N$ Engl J Med 2001, 345:1359-1367.

68. Van den Berghe G, Wilmer A, Hermans G, Meersseman W, Wouters PJ, Milants I, Van Wijngaerden E, Bobbaers H, Bouillon $\mathrm{R}$ : Intensive insulin therapy in the medical ICU. $N$ Engl J Med 2006, 354:449-461.

69. Schetz M, Vanhorebeek I, Wouters PJ, Wilmer A, Van den Berghe G: Tight blood glucose control is renoprotective in critically ill patients. J Am Soc Nephrol 2008,

70. Van den Berghe G, Wouters PJ, Bouillon R, Weekers F, Verwaest C, Schetz M, Vlasselaers D, Ferdinande P, Lauwers P: Outcome benefit of intensive insulin therapy in the critically ill: insulin dose versus glycemic control. Crit Care Med 2003, 31:359366.

71. Ellger B, Debaveye Y, Vanhorebeek I, Langouche L, Giulietti A, Van Etten E, Herijgers P, Mathieu C, Van den Berghe G: Survival benefits of intensive insulin therapy in critical illness: impact of maintaining normoglycemia versus glycemia-independent actions of insulin. Diabetes 2006, 55:1096-1105.

72. Mesotten D, Swinnen JV, Vanderhoydonc F, Wouters PJ, Van den Berghe $\mathrm{G}$ : Contribution of circulating lipids to the improved outcome of critical illness by glycemic control with intensive insulin therapy. J Clin Endocrinol Metab 2004, 89:219-226.

73. Langouche L, Vander Perre S, Wouters PJ, D'Hoore A, Hansen TK, Van den Berghe G: Effect of intensive insulin therapy on insulin sensitivity in the critically ill. J Clin Endocrinol Metab 2007, 92:3890-3897.

74. Brunkhorst FM, Engel C, Bloos F, Meier-Hellmann A, Ragaller M, Weiler N, Moerer O, Gruendling M, Oppert M, Grond S, Olthoff D, Jaschinski U, John S, Rossaint R, Welte T, Schaefer M, Kern P, Kuhnt E, Kiehntopf M, Hartog C, Natanson C, Loeffler M, Reinhart $\mathrm{K}$ : Intensive insulin therapy and pentastarch resuscitation in severe sepsis. N Engl J Med 2008, 358:125-139.

75. Ishibashi N, Plank LD, Sando K, Hill GL: Optimal protein requirements during the first 2 weeks after the onset of critical illness. Crit Care Med 1998, 26:1529-1535.

76. Bongers T, Griffiths RD, McArdle A: Exogenous glutamine: the clinical evidence. Crit Care Med 2007, 35:S545-S552.

77. Berger MM, Shenkin A: Vitamins and trace elements: practical aspects of supplementation. Nutrition 2006, 22:952-955.

78. Berger MM, Shenkin A: Update on clinical micronutrient supplementation studies in the critically ill. Curr Opin Clin Nutr Metab Care 2006, 9:711-716.

79. Heyland DK, Dhaliwal R, Suchner U, Berger MM: Antioxidant nutrients: a systematic review of trace elements and vitamins in the critically ill patient. Intensive Care Med 2005, 31:327337.

80. Angstwurm MW, Engelmann L, Zimmermann T, Lehmann C, Spes $\mathrm{CH}$, Abel P, Strauss R, Meier-Hellmann A, Insel R, Radke J, Schuttler J, Gartner R: Selenium in Intensive Care (SIC): results of a prospective randomized, placebo-controlled, multiple-center study in patients with severe systemic inflammatory response syndrome, sepsis, and septic shock. Crit Care Med 2007, 35: 118-126.

81. Metnitz GH, Fischer M, Bartens C, Steltzer H, Lang T, Druml W: Impact of acute renal failure on antioxidant status in multiple organ failure. Acta Anaesthesio/ Scand 2000, 44:236-240.

82. Cano N, Fiaccadori E, Tesinsky P, Toigo G, Druml W, Kuhlmann M, Mann H, Horl WH: ESPEN Guidelines on Enteral Nutrition: Adult renal failure. Clin Nutr 2006, 25:295-310.

83. Calder PC: Immunonutrition in surgical and critically ill patients. Br J Nutr 2007, 98 Suppl 1:S133-S139.

84. Bertolini G, lapichino G, Radrizzani D, Facchini R, Simini B, Bruzzone $P$, Zanforlin G, Tognoni G: Early enteral immunonutrition in patients with severe sepsis: results of an interim analysis of a randomized multicentre clinical trial. Intensive Care Med 2003, 29:834-840.

85. Jones NE, Heyland DK: Pharmaconutrition: a new emerging paradigm. Curr Opin Gastroenterol 2008, 24:215-222.

86. Bonventre JV: Pathophysiology of acute kidney injury: roles of potential inhibitors of inflammation. Contrib Nephrol 2007 156:39-46.

87. Kieft H, Roos AN, van Drunen JD, Bindels AJ, Bindels JG, Hofman $\mathrm{Z}$ : Clinical outcome of immunonutrition in a heterogeneous intensive care population. Intensive Care Med 2005, 31:524-532. 
88. Beale RJ, Sherry T, Lei K, Campbell-Stephen L, McCook J, Smith J, Venetz W, Alteheld B, Stehle P, Schneider H: Early enteral supplementation with key pharmaconutrients improves Sequential Organ Failure Assessment score in critically ill patients with sepsis: outcome of a randomized, controlled, double-blind trial. Crit Care Med 2008, 36:131-144.

89. Barr J, Hecht M, Flavin KE, Khorana A, Gould MK: Outcomes in critically ill patients before and after the implementation of an evidence-based nutritional management protocol. Chest 2004, 125:1446-1457.

90. Martin CM, Doig GS, Heyland DK, Morrison T, Sibbald WJ: Multicentre, cluster-randomized clinical trial of algorithms for critical-care enteral and parenteral therapy (ACCEPT). CMAJ 2004, 170:197-204.

91. Kochevar M, Guenter P, Holcombe B, Malone A, Mirtallo J: ASPEN statement on parenteral nutrition standardization. JPEN J Parenter Enteral Nutr 2007, 31:441-448.

92. Abel RM, Beck CH Jr., Abbott WM, Ryan JA Jr., Barnett GO, Fischer JE: Improved survival from acute renal failure after treatment with intravenous essential L-amino acids and glucose. Results of a prospective, double-blind study. $N$ Engl $J$ Med 1973, 288:695-699.

93. Baek SM, Makabali GG, Bryan-Brown CW, Kusek J, Shoemaker WC: The influence of parenteral nutrition on the course of acute renal failure. Surg Gynecol Obstet 1975, 141:405-408.

94. Feinstein El, Blumenkrantz MJ, Healy M, Koffler A, Silberman H, Massry SG, Kopple JD: Clinical and metabolic responses to parenteral nutrition in acute renal failure. A controlled doubleblind study. Medicine (Baltimore) 1981, 60:124-137.

95. Fiaccadori E, Maggiore U, Giacosa R, Rotelli C, Picetti E, Sagripanti $\mathrm{S}$, Melfa L, Meschi T, Borghi L, Cabassi A: Enteral nutrition in patients with acute renal failure. Kidney Int 2004, 65:999-1008.

96. Metnitz PG, Krenn CG, Steltzer H, Lang T, Ploder J, Lenz K, Le Gall JR, Druml W: Effect of acute renal failure requiring renal replacement therapy on outcome in critically ill patients. Crit Care Med 2002, 30:2051-2058.

97. Sorkine $P$, Halpern $P$, Scarlat A, Weinbroum A, Silbiger A, Setton $A$, Rudick V: Metabolic effects of continuous veno-venous haemofiltration in critically ill patients. Clin Intensive Care 1994, 5:293-295.

98. Matamis D, Tsagourias M, Koletsos K, Riggos D, Mavromatidis K, Sombolos K, Bursztein S: Influence of continuous haemofiltration-related hypothermia on haemodynamic variables and gas exchange in septic patients. Intensive Care Med 1994, 20:431436.

99. Manns M, Maurer E, Steinbach B, Evering HG: Thermal energy balance during in vitro continuous veno-venous hemofiltration. ASAIO J 1998, 44:M601-M605.

100. Rokyta R Jr., Matejovic M, Krouzecky A, Opatrny K Jr., Ruzicka J, Novak I: Effects of continuous venovenous haemofiltrationinduced cooling on global haemodynamics, splanchnic oxygen and energy balance in critically ill patients. Nephrol Dial Transplant 2004, 19:623-630.

101. Gutierrez A, Alvestrand A, Wahren J, Bergstrom J: Effect of in vivo contact between blood and dialysis membranes on protein catabolism in humans. Kidney Int 1990, 38:487-494.

102. Gutierrez A, Bergstrom J, Alvestrand A: Hemodialysis-associated protein catabolism with and without glucose in the dialysis fluid. Kidney Int 1994, 46:814-822.

103. Fiaccadori E, Maggiore U, Rotelli C, Giacosa R, Picetti E, Parenti E, Meschi T, Borghi L, Tagliavini D, Cabassi A: Effects of different energy intakes on nitrogen balance in patients with acute renal failure: a pilot study. Nephrol Dial Transplant 2005, 20: 1976-1980.

104. Bellomo R, Seacombe J, Daskalakis M, Farmer M, Wright C, Parkin G, Boyce N: A prospective comparative study of moderate versus high protein intake for critically ill patients with acute renal failure. Ren Fail 1997, 19:111-120.

105. Bellomo R, Tan HK, Bhonagiri S, Gopal I, Seacombe J, Daskalakis $\mathrm{M}$, Boyce N: High protein intake during continuous hemodiafiltration: impact on amino acids and nitrogen balance. Int $J$ Artif Organs 2002, 25:261-268.

106. Scheinkestel CD, Kar L, Marshall K, Bailey M, Davies A, Nyulasi I, Tuxen DV: Prospective randomized trial to assess caloric and protein needs of critically III, anuric, ventilated patients requiring continuous renal replacement therapy. Nutrition 2003, 19: 909-916.
107. Bellomo R, Colman PG, Caudwell J, Boyce N: Acute continuous hemofiltration with dialysis: effect on insulin concentrations and glycemic control in critically ill patients. Crit Care Med 1992, 20:1672-1676.

108. Bonnardeaux A, Pichette V, Ouimet D, Geadah D, Habel F, Cardinal J: Solute clearances with high dialysate flow rates and glucose absorption from the dialysate in continuous arteriovenous hemodialysis. Am J Kidney Dis 1992, 19:31-38.

109. Monaghan R, Watters JM, Clancey SM, Moulton SB, Rabin EZ: Uptake of glucose during continuous arteriovenous hemofiltration. Crit Care Med 1993, 21:1159-1163.

110. Frankenfield DC, Reynolds HN, Badellino MM, Wiles CE III: Glucose dynamics during continuous hemodiafiltration and total parenteral nutrition. Intensive Care Med 1995, 21:1016-1022.

111. Oudemans-van Straaten HM: Primum non nocere, safety of continuous renal replacement therapy. Curr Opin Crit Care 2007, 13:635-637.

112. Chiolero R, Mavrocordatos $P$, Burnier $P$, Cayeux MC, Schindler $C$, Jequier E, Tappy L: Effects of infused sodium acetate, sodium lactate, and sodium beta-hydroxybutyrate on energy expenditure and substrate oxidation rates in lean humans. Am J Clin Nutr 1993, 58:608-613.

113. Vriesendorp TM, van Santen S, DeVries JH, de Jonge $E$, Rosendaal FR, Schultz MJ, Hoekstra JB: Predisposing factors for hypoglycemia in the intensive care unit. Crit Care Med 2006, 34:96-101

114. Bollmann MD, Revelly JP, Tappy L, Berger MM, Schaller MD, Cayeux MC, Martinez A, Chiolero RL: Effect of bicarbonate and lactate buffer on glucose and lactate metabolism during hemodiafiltration in patients with multiple organ failure. Intensive Care Med 2004, 30:1103-1110.

115. Tan HK, Uchino S, Bellomo R: Electrolyte mass balance during CVVH: lactate vs. bicarbonate-buffered replacement fluids. Ren Fail 2004, 26:149-153.

116. Frankenfield DC, Badellino MM, Reynolds HN, Wiles CE III, Siegel $\mathrm{JH}$, Goodarzi S: Amino acid loss and plasma concentration during continuous hemodiafiltration. JPEN J Parenter Enteral Nutr 1993, 17:551-561.

117. Davenport A, Roberts NB: Amino acid losses during continuous high-flux hemofiltration in the critically ill patient. Crit Care Med 1989, 17:1010-1014.

118. Davies SP, Reaveley DA, Brown EA, Kox WJ: Amino acid clearances and daily losses in patients with acute renal failure treated by continuous arteriovenous hemodialysis. Crit Care Med 1991, 19:1510-1515.

119. Novak I, Sramek V, Pittrova H, Rusavy P, Lacigova S, Eiselt M, Kohoutkova L, Vesela E, Opatrny K Jr.: Glutamine and other amino acid losses during continuous venovenous hemodiafiltration. Artif Organs 1997, 21:359-363.

120. Scheinkestel CD, Adams F, Mahony L, Bailey M, Davies AR Nyulasi I, Tuxen DV: Impact of increasing parenteral protein loads on amino acid levels and balance in critically ill anuric patients on continuous renal replacement therapy. Nutrition 2003, 19:733-740.

121. Bellomo R, Martin H, Parkin G, Love J, Kearley Y, Boyce N: Continuous arteriovenous haemodiafiltration in the critically ill: influence on major nutrient balances. Intensive Care Med 1991, 17:399-402.

122. Story DA, Ronco C, Bellomo R: Trace element and vitamin concentrations and losses in critically ill patients treated with continuous venovenous hemofiltration. Crit Care Med 1999, 27:220-223.

123. Berger MM, Shenkin A, Revelly JP, Roberts E, Cayeux MC, Baines $\mathrm{M}$, Chiolero RL: Copper, selenium, zinc, and thiamine balances during continuous venovenous hemodiafiltration in critically ill patients. Am J Clin Nutr 2004, 80:410-416.

124. Nakamura AT, Btaiche IF, Pasko DA, Jain JC, Mueller BA: In vitro clearance of trace elements via continuous renal replacement therapy. J Ren Nutr 2004, 14:214-219.

125. Churchwell MD, Pasko DA, Btaiche IF, Jain JC, Mueller BA: Trace element removal during in vitro and in vivo continuous haemodialysis. Nephrol Dial Transplant 2007, 22:2970-2977.

126. Klein CJ, Moser-Veillon PB, Schweitzer A, Douglass LW, Reynolds HN, Patterson KY, Veillon C: Magnesium, calcium, zinc, and nitrogen loss in trauma patients during continuous renal replacement therapy. JPEN J Parenter Enteral Nutr 2002, 26:77-92. 
Critical Care Vol 12 No 4 Casaer et al.

127. Christensen ML: Parenteral formulations. In Nutrition Therapy for the Critically III Patient: A Guide to Practice. Edited by Cresci

G. Boca Raton: CRC Press; 2005:279-299. 